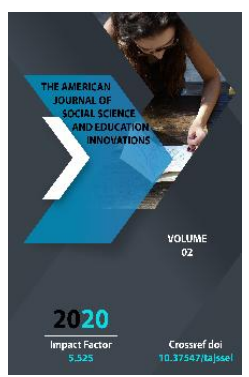

\title{
The Continuous Professional Development For EFL Teachers Of Higher Education
}

\author{
Halimahon Muhammadiyeva \\ EFL Teacher Of The Department Of Practical Course Of English Language, Namangan State \\ University, Uzbekistan
}

Journal Website:

http://usajournalshub.c

om/index,php/tajssei

Copyright: Original

content from this work

may be used under the

terms of the creative

commons attributes

4.0 licence.

\section{ABSTRACT}

In global outbreak period of Quarantine (covid-19), Continuous Professional Development (CPD) for EFL teachers of higher education is more highlighted in this article. In terms of CPD activities, the teachers always need higher cognition about the importance of self-initiated professional development. They should acknowledge that the self-driven activities and tasks of professionalism act the significant roles in bringing about real change on teachers' pedagogical effectiveness and efficiency.

\section{KEYWORDS}

Continuous Professional Development (CPD), EFL teacher, Peer coaching, doing Action Research $(A R)$, teaching portfolio, mentoring

\section{INTRODUCTION}

In today's nationwide quarantine in connection with a global outbreak of Corona virus, it has become as an actual topic to promote CPD for EFL teachers of higher education. There are many innovative ways of CPD which include workshops, webinars, free online courses and any similar CPD activities that can contribute significantly to the development of EFL teachers around the world, at both pre-service and in-service levels, and countless ELT professionals who have experienced fulfilling CPD that is 
delivered via structured input-based courses and programmes. CPD by providing these mandated workshops, which are often delivered by professional trainers. $[\mathrm{H}$. Muhammadiyeva, 2020]

Continuous Professional Development (CPD) has been defined in various ways such as:

$>$ CPD is an inclusion of in-service training and workshops.

$>$ CPD is a process in which teachers work under supervision to gain experiences.

$>$ CPD is an ongoing learning process in which teachers primarily aim at how to teach in accordance with the expectations and needs of the students.

According to the scholars such as Timperley, Wilson, Barrar \& Fung, Richards \& Farrell who have done researches on the term CPD does not refer to only one concept as it includes many different principles

The characteristics of CPD:

$>$ CPD should be relevant to the needs of teachers and their students

$>$ CPD should involve teacher collaboration

$>$ CPD should be supported from the university leadership

$>$ CDP should show critical engagement with received knowledge

$>$ CDP should value teachers' experience and knowledge.

CPD with these features is more likely to conceive of the teacher as a knowledge generator. In other words, we should understand that CPD not only a strategy through which teachers acquire knowledge from external sources but also, teachers can engage in (collective) professional atmosphere in doing action research, peer observation, and teacher support groups, peer-coaching, study groups, mentoring, teaching portfolios, in-service training, team teaching, presenting the findings of a study done on professional development and effective professional development strategies used by EFL teachers of higher education.

\section{MATERIALS AND METHODS}

\section{Peer-Coaching}

Peer coaching is a process of two teachers who provide each other with feedback and advice about their teaching. In peer coaching, each teacher acts as both the coach and the coachee. According to Thorn et al. (2007), peer coaching has benefits as follows:

$>$ Reduce isolation among leaders

$>$ Establish collaborative norms

> Build a shared knowledge base

$>$ Share successful practices

$>$ Encourage reflective practice

$>$ More cohesive organizational culture

In short, peer couching provides supportive and developmental context for the teachers and it is very beneficial for especially language teachers who need to learn and use new language items and cultural practices.

\section{Doing Action Research}

According to Ferrance, doing Action Research $(A R)$ is a process in which teachers examine their own educational practice systematically and carefully, using the techniques of research (Ferrance, 2000). By doing AR, teachers work on the problems they have faced in the classroom and help each other collaboratively. The scholar Nunan provides some guidelines for doing action research:

$>$ Select your setting

$>$ Identify what you want to evaluate

$>$ Select or design your data collection procedure

$>$ Collect the data 
$>$ Analyze these findings with reference to your original purposes(Nunan,1992, p.4)

\section{Teaching Portfolios}

According to Seldin, teaching portfolio can be helpful for teachers' continuous professional development in terms of course planning and preparation, actual teaching presentation, evaluation and feedback provision process, and currency in the field (Seldin, 1993). Thus, Edgerton et al. (1991) describe portfolios as follows:

$>$ Portfolios provide documented evidence of teaching that is connected to the specifics and contexts of what is being taught.

> They go beyond exclusive reliance on student ratings because they include a range of evidence from a variety of sources such as syllabi, samples of student work, self-reflections, reports on classroom research, and faculty development efforts.

$>$ In the process of selecting and organizing their portfolio material, faculty think hard about their teaching, a practice which is likely to lead to improvement in practice.

$>$ In deciding what should go into a portfolio and how it should be evaluated, institutions necessarily must address the question of what is effective teaching and what standards should drive campus teaching practice.

> Portfolios are a step toward a more public, professional view of teaching. They reflect teaching as a scholarly activity.

\section{Mentoring}

Butcher defines Mentoring as a form of personal and professional partnership which generally involves a more experienced practitioner supporting a less experienced one who is usually new to the job, organization or profession (Butcher,2002). According to Malderez\&Bodóczky and Fletcher, Mentoring requires for mentors to be masters of certain standard practices including such abilities as:

$>$ Observe lessons analytically

> Make explicit their craft knowledge

$>$ Give appropriate and useful feedback on teaching

$>$ Notice and take advantages of learning opportunities

$>$ Set suitable targets for mentee development

$>$ Assess and analyze a teacher's strengths and weaknesses (Malderez\&Bodóczky, 1999; Fletcher,2000)

\section{RESULTS AND DISCUSSIONS}

There are great ideas and recommendations for upgrading CPD for EFL teachers of higher education.

-Publish reviews, articles in the magazines, teaching tips, lesson plans in the newsletter of a local teaching organization, flashcards, worksheets, conference report, blog posts (on your own or other people's blogs), etc.

-Read blogs and blog comments, online forums, books of practical ideas, articles, book reviews, magazines, journals, email newsletters (e.g. Oxford teachers club.com), e-books, relevant popular science books (e.g. ones of learning or psychology), linguistics books, etc.

-Research on classroom investigation, student opinions, what teachers really do while teaching, planning, marking or choosing jobs, the effects of something on learning, common teaching mistakes, the development language competences and etc.

- Set up online book club, tea chat, and etc. 
- Share worksheets (e.g. on ESLprintables, Scribd.com), teaching ideas (e.g. on a notice board in your teachers' room), favourite worksheets (e.g. in level files or a sharing file in your teachers' room), warm ups, lesson plans (e,g. on Onestopenglish Lesson Share), your favourite links (e.g. oup.com) and etc.

- $\quad$ Subscribe to website updates (e.g. TESOL updates), magazines and journals (e.g. ELT Journal, English Teaching Professional, Modern English Teacher), Google News Alerts in things of interest (e.g. "Second Language Acquisition" or "ELT publishing")

- Join and take part in online courses, CEFR, TEFL or TESOL, IELTS courses, webinars, Yahoo groups, and Telegram groups.

- Be a volunteer or a mentor to help organise and run online conference, organise the teaching resources, organise and lead a series of workshops, find out about the possibility of becoming a teacher training centre

- Watch online workshops or lectures, a videoed lesson (e.g. the DVDs at the back of Teaching with Bear and The Practice of English Language Teaching), a colleague's lesson, a video of your own lesson, webinars, movies about teaching, videos on the CD ROMs in the publishers' latest catalogues

- Write a teaching diary, a list of your beliefs about teaching and learning, your answers to discussion questions in the teaching book you are reading, a brainstormed list of ways to teach or practice something, a list of things that worked well and etc. [ $\mathrm{H}$. Muhammadiyeva, 2020]

\section{CONCLUSION}

In conclusion, we should understand that CPD not only a strategy through which teachers acquire knowledge from external sources but also, teachers can engage in (collective) professional atmosphere in doing action research, peer observation, and teacher support groups, peer-coaching, study groups, mentoring, teaching portfolios, in-service training, team teaching, presenting the findings of a study done on professional development and effective professional development strategies used by EFL teachers of higher education.

\section{REFERENCES}

1. Butcher, J. (2002). 'A case for mentor challenge? The problem of learning to teach post'. Mentoring and Tutoring. 10(3), p. 197-220.

2. Clarke, D. M. (1994). Ten key principles from research for the professional development of mathematics teachers. In D. B. Aichele \& A. F.Croxford (Eds.). Professional development for teachers of mathematics (pp. 37-48). Reston, VA: NCTM.

3. Clarke, D. M. (2001). Understanding, assessing and developing young children's mathematical thinking: Research as powerful tool for professional growth. In J. Bobis, B. Perry, \& M. Mitchelmore (Eds.), Numeracy and beyond (Proceedings of the 24th Annual Conference of the Mathematics Education Research Group of Australasia, Vol. 1, pp. 9-26). Sydney: MERGA.

4. Clarke, D. M. (2003). Effective professional development: What does research say? (ACU/CEO Research 
Monograph Series). Melbourne, Australia: Mathematics Teaching and Learning Centre, Australian Catholic University.

5. Richards, J. \& Farrell, T. 2005. Professional Development for Language Teachers. Strategies for Teacher Learning. Cambridge: Cambridge University Press.

6. Ferrance, E. (2000). Action Research. Themes in Education. Northeast and Islands Regional Educational Laboratory at Brown University. USA

7. Malderez, A. and C. Bodóczky. (1999). Mentor Courses. Cambridge: Cambridge University Press.

8. Nunan, D. (1992). Research Methods in Language Learning. Cambridge: Cambridge University Press.

9. Fletcher, S. (2000). Mentoring in Schools: A Handbook of Good Practice. London: Kogan Page.

10. Seldin, Peter and Associates. (1993). Successful Use of Teaching Portfolios. Belton, MA: Anker Publishing.

11. Thorn et al. (2007). Peer Coaching Overview. Available online at: www.marshallgoldsmithlibrary.com

12. H.Muhammadiyeva, (2020).Distance Professional Learning for English teachers. International Journal of Word Art. ISSN 2181-9297 Doi Journal 10.26739/2181-9297

13. Muhamadjonovna, S. D. (2020). The key concepts of forming sociolinguistic competence of future English language specialists. Asian Journal of Multidimensional Research (AJMR), 9(5), 118-121.

14. Muhamadjonovna, S. D. (2020). The development of sociolinguistic competence of future English language teachers through computer technologies.
15. Sarimsakova, D., \& Rashidova, S. (2017). DEVELOPING INTERCULTURAL COMPETENCES WITH CASE STUDIES. In WORLD SCIENCE: PROBLEMS AND INNOVATIONS (pp. 212-214).

16. Sarimsakova, D. (2019). Communicative competence as a result of EF teaching and learning ISJ Theoretical \& Applied Science, 12 (80), 166-169 https://dx. doi. org/10.15863. In TAS (Vol. 80). 